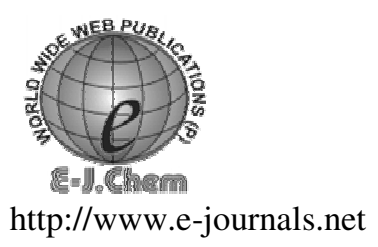

\title{
Correlation Study on Physico-Chemical Parameters and Quality Assessment of Kosi River Water, Uttarakhand
}

\author{
NARENDRA SINGH BHANDARI and KAPIL NAYAL \\ Department of Chemistry, Kumaun University, \\ Soban Singh Jeena Campus, Almora-263601, Uttarakhand, India \\ im_nsbhandari@yahoo.co.in
}

Received 7 October 2007; Accepted 10 December 2007

\begin{abstract}
Present work deals with the assessment of physico-chemical parameters of water samples of Kosi river at Kosi sampling station during 2004 and 2005 in pre monsoon, monsoon and post monsoon seasons. Statistical studies have been carried out by calculating correlation coefficients between different pairs of parameters and $t$ - test applied for checking significance. The observed values of various physico-chemical parameters of water samples were compared with standard values recommended by WHO. It is found that an appreciable significant positive correlation holds for chloride with $\mathrm{pH}, \mathrm{Mg}, \mathrm{Na}$, hardness and total suspended solid; and sodium with hardness, EC and sulphate. A significant negative correlation was found between potassium with turbidity, $\mathrm{Cl}^{-}, \mathrm{EC}$ and hardness. All the physicochemical parameters of Kosi water are within the highest desirable limit or maximum permissible limit set by WHO except turbidity and BOD which recorded a high value.
\end{abstract}

Keywords: Chemical composition, Statistical analysis, $t$ - test, Potability.

\section{Introduction}

In India ponds, rivers and ground water are used for domestic and agricultural purposes. The quality of water may be described according to their physico-chemical and micro-biological characteristics. For effective maintenance of water quality through appropriate control measures, continuous monitoring of large number of quality parameters is essential. However it is very difficult and laborious task for regular monitoring of all the parameters even if adequate manpower and laboratory facilities are available. Therefore, in recent years an alternative approach based on statistical correlation, has been used to develop mathematical relationship for comparison of physico-chemical parameters ${ }^{1-3}$.

The present study deals with study of physico-chemical parameters of Kosi river water in Uttarakhand. The analyzed data were compared with standard values recommended by WHO. 
Systematic calculation of correlation coefficient between water quality parameters has been done with the objective of minimizing the complexity and dimensionality of large set of data. The significant correlation has been further verified by using $t$-test.

\section{Experimental}

Water samples were collected from sampling station, Kosi in pre monsoon, monsoon and post monsoon seasons for two consecutive years, 2004 and 2005. All the chemicals used were of AR grade. $\mathrm{pH}$, electrical conductivity and turbidity were measured by using MAC Digital Portable Kit (MSW-551). Flame photometer (Model Systronic 128) was used for determination of metal ions $\mathrm{Na}^{+}, \mathrm{K}^{+}$and $\mathrm{Ca}^{2+}$. Silver nitrate method was used to estimate the chloride present in water samples ${ }^{4 \mathrm{a}}$. Sulphate was determined by turbidimetric method ${ }^{4 \mathrm{~b}}$. Total hardness was calculated by complexometric titration using EDTA ${ }^{4 \mathrm{c}}$.

The statistical analysis has been performed using standard methods ${ }^{5}$. Karl-Pearson correlation coefficient (r) was calculated and correlation for significance has also been tested by applying $t$-test ${ }^{6}$.

\section{Results and Discussion}

The standard and observed values of physico-chemical parameters of experimental water samples are presented in Table 1.The observed $\mathrm{pH}$ values ranging from 8.1 to 8.7 shows that the present water samples are slightly alkaline. These values are within maximum permissible limit prescribed by $\mathrm{WHO}^{7}$. The calcium $(4.9-58.6 \mathrm{mg} / \mathrm{L})$, chloride $(0.12-0.17 \mathrm{mg} / \mathrm{L}), \mathrm{SO}_{4}{ }^{2-}$ (0.32-0.45 mg/L), hardness (70-495 mg/L), TDS (24.3-54.3 mg/L) values of water samples are within the highest desirable or maximum permissible limit set by $\mathrm{WHO}^{8}$. Since no prescribed standards are suggested by WHO for parameters like electrical conductivity, sodium and potassium content for drinking purpose. So, no comparison can be made from observed values.

Table.1. The average values of physico-chemical parameters of Kosi River water.

\begin{tabular}{|c|c|c|c|}
\hline \multirow{2}{*}{ Parameters } & \multicolumn{2}{|c|}{ WHO Standards } & \multirow{2}{*}{$\begin{array}{c}\text { Experimental } \\
\text { Values (Range) } \\
\mathrm{mg} / \mathrm{L}\end{array}$} \\
\hline & HDL & MPL & \\
\hline $\mathrm{pH}$ & $7-8.5$ & $6.5-9.5$ & $8.1-8.7$ \\
\hline $\mathrm{EC}$ & - & - & $0.123-0.139^{*}$ \\
\hline $\mathrm{Na}^{+}$ & - & 200 & $8.4-8.8$ \\
\hline $\mathrm{K}^{+}$ & - & - & $2-2.93$ \\
\hline $\mathrm{Ca}^{2+}$ & 75 & 200 & $49.0-58.6$ \\
\hline $\mathrm{Mg}^{2+}$ & 30 & 150 & $75.24-86.4$ \\
\hline $\mathrm{NO}_{3}^{-}$ & 45 & 45 & $0.041-0.05$ \\
\hline $\mathrm{Cl}^{-}$ & 200 & 600 & $0.12-0.17$ \\
\hline TDS & 500 & 1000 & $24.3-54.3$ \\
\hline TSS & - & - & $4.3-10.66$ \\
\hline HRD & 100 & 500 & $70-495$ \\
\hline $\mathrm{SO}_{4}{ }^{2-}$ & 200 & 400 & $0.32-0.45$ \\
\hline $\mathrm{PO}_{4}^{3-}$ & - & - & $0.04-0.063$ \\
\hline COD & - & - & $21.33-24$ \\
\hline Turbidity & 5 & - & $8-11.6^{* *}$ \\
\hline BOD & 1.3 & - & $6.56-9.03$ \\
\hline
\end{tabular}

HDL: Highest desirable Limit; MPL: Maximum permissible limit, ${ }^{*}$ EC in $\mathrm{dsm}^{-1 ;} * *$ Turbidity in NTU. 
Table 2. .Different pair of correlations

\begin{tabular}{|c|c|c|c|}
\hline Parameters & Parameters & $r$ & $|t|$ \\
\hline \multirow[t]{3}{*}{$\mathrm{EC}$} & TSS & -0.8868 & 3.9316 \\
\hline & TDS & -0.9477 & 5.9386 \\
\hline & HRD & -0.8979 & 4.0795 \\
\hline \multirow[t]{6}{*}{$\mathrm{Na}$} & $\mathrm{NO}_{3}^{-}$ & -0.6272 & 1.6105 \\
\hline & $\mathrm{SO}_{4}^{2-}$ & -0.9353 & 5.2863 \\
\hline & TDS & -0.9353 & 6.2982 \\
\hline & TSS & -0.9666 & 7.5430 \\
\hline & HRD & -0.993 & 16.8142 \\
\hline & $\mathrm{EC}$ & -0.9224 & 4.7763 \\
\hline \multirow[t]{5}{*}{ K } & TSS & 0.7933 & 2.6059 \\
\hline & Turbidity & -0.7605 & 2.3423 \\
\hline & $\mathrm{Cl}$ & -0.8686 & 3.5058 \\
\hline & $\mathrm{EC}$ & -0.6778 & 1.8437 \\
\hline & HRD & -0.7351 & 2.1685 \\
\hline \multirow[t]{5}{*}{$\mathrm{Mg}$} & Turbidity & 0.8771 & 3.6504 \\
\hline & $\mathrm{pH}$ & 0.8436 & 3.1420 \\
\hline & $\mathrm{SO}_{4}{ }^{2-}$ & 0.7831 & 2.5184 \\
\hline & TSS & -0.8025 & 2.6900 \\
\hline & HRD & -0.7954 & 2.642 \\
\hline \multirow[t]{5}{*}{$\mathrm{Cl}^{-}$} & $\mathrm{pH}$ & 0.8748 & 3.6112 \\
\hline & HRD & 0.8121 & 2.7834 \\
\hline & TSS & 0.8874 & 3.8498 \\
\hline & $\mathrm{Na}$ & 0.7442 & 2.2282 \\
\hline & $\mathrm{Mg}$ & 0.8211 & 2.8770 \\
\hline TDS & TSS & 0.9056 & 4.2703 \\
\hline TSS & $\mathrm{pH}$ & -0.7887 & 2.5658 \\
\hline \multirow[t]{2}{*}{ TSS } & $\mathrm{Ca}$ & 0.1346 & 2.1653 \\
\hline & TDS & 0.8037 & 2.7013 \\
\hline \multirow[t]{2}{*}{ HRD } & TSS & -0.9878 & 12.6862 \\
\hline & $\mathrm{pH}$ & 0.7379 & 2.1866 \\
\hline \multirow{6}{*}{$\mathrm{SO}_{4}{ }^{2-}$} & $\mathrm{pH}$ & 0.7537 & 2.2936 \\
\hline & HRD & 0.9392 & 5.4704 \\
\hline & TSS & -0.8991 & 4.1078 \\
\hline & Turbidity & 0.8543 & 3.2871 \\
\hline & $\mathrm{EC}$ & 0.8061 & 2.7263 \\
\hline & TDST & -0.9207 & 4.7182 \\
\hline \multirow[t]{5}{*}{ Turbidity } & HRD & 0.91 & 4.3896 \\
\hline & TSSD & -0.8816 & 3.7356 \\
\hline & $\mathrm{EC}$ & 0.7465 & 2.2438 \\
\hline & $\mathrm{Cl}^{-}$ & 0.7405 & 2.203 \\
\hline & TDS & -0.8703 & 3.5340 \\
\hline \multirow[t]{5}{*}{ BOD } & $\mathrm{Cl}^{-}$ & 0.9027 & 4.125 \\
\hline & $\mathrm{EC}$ & 0.743 & 2.606 \\
\hline & HRD & 0.9640 & 2.479 \\
\hline & $\mathrm{Mg}$ & 0.885 & 3.8039 \\
\hline & Turbidity & 0.883 & 3.770 \\
\hline
\end{tabular}

Note: Significant if t $0.05>2.132$ 
In the present study for the years 2004 and 2005 EC has strong significant negative correlation with TSS $(\mathrm{r}=-0.8865, \mathrm{t}=3.9316)$, TDS $(\mathrm{r}=-0.9477, \mathrm{t}=5.9386)$ and hardness $(\mathrm{r}=-0.8979, \mathrm{t}=4.0795)$. This shows that with increase or decrease in the values of EC; TSS, TDS and HRD also exhibit decrease or increase in their values.

A significant positive correlation was found between $\mathrm{Na}$ and HRD $(\mathrm{r}=0.993$, $\mathrm{t}=16.8142), \mathrm{EC}(\mathrm{r}=0.9224, \mathrm{t}=4.7763), \mathrm{SO}_{4}{ }^{2-}(\mathrm{r}=0.9353, \mathrm{t}=5.2863)$. Sodium showed negative significant correlation with $\mathrm{NO}_{3}{ }^{-}(\mathrm{r}=0.6272, \mathrm{t}=1.6105)$, TDS $(\mathrm{r}=0.9353$, $\mathrm{t}=6.2982)$, TSS $(\mathrm{r}=-0.9666, \mathrm{t}=7.5430)$. so with increase or decrease in the values of $\mathrm{Na}$, the values of HRD, EC and $\mathrm{SO}_{4}{ }^{2-}$ increases or decreases while $\mathrm{NO}_{3}^{-}$, TDS, TSS decreases or increases with increasing or decreasing in values of $\mathrm{Na}$. Potassium showed positive correlation with TSS $(r=0.7933, t=1.6059)$. A significant negative correlation was found between potassium with turbidity $(\mathrm{r}=-0.7605, \mathrm{t}=2.3423), \mathrm{Cl}^{-}(\mathrm{r}=0.8686, \mathrm{t}=3.5058)$, EC $(\mathrm{r}=-0.6778, \mathrm{t}=1.8437)$ and HRD $(\mathrm{r}=-0.7351, \mathrm{t}=2.1685)$. The magnesium content of Kosi water increases or decreases with increase or decrease in the value of turbidity, $\mathrm{pH}, \mathrm{HRD}$ and $\mathrm{SO}_{4}{ }^{2-}$, as it shows significant positive correlation with these parameters ${ }^{9,10}$.

Chloride ion bears significant positive correlation with $\mathrm{pH}(\mathrm{r}=0.748, \mathrm{t}=3.6112), \mathrm{Mg}$ $(\mathrm{r}=0.821, \mathrm{t}=2.8770), \mathrm{Na}(\mathrm{r}=0.7442, \mathrm{t}=2.2282)$, HRD $(\mathrm{r}=0.8121, \mathrm{t}=2.7834)$, TSSD $(\mathrm{r}=0.8874, \mathrm{t}=3.8498)$ and sulphate ion does not bear significant positive correlation with $\mathrm{Mg}$ and $\mathrm{Na}$. It reveals that $\mathrm{Mg}^{2+}$ mainly remains present as $\mathrm{MgCl}_{2}$ and $\mathrm{Na}^{+}$as $\mathrm{NaCl}$. $\mathrm{Cl}^{-}$ions bear negative correlation with $\mathrm{K}^{+}$. It indicates that $\mathrm{KCl}$ may be absent in water samples. Total hardness bears positive correlation with $\mathrm{Mg}$ and $\mathrm{Na}^{+}$. So it is suggested that total hardness of water samples is mainly due to the presence of the $\mathrm{MgCl}_{2}$ and $\mathrm{NaCl}^{11}$.

Total dissolved solid shows significant positive correlation with TSS $(r=0.3056, \mathrm{t}=4.278)$ and TSS shows significant positive correlation with $\mathrm{pH}(\mathrm{r}=-0.7887, \mathrm{t}=2.5658)$. TSS shows significant positive correlation with $\mathrm{Ca}(\mathrm{r}=0.7346, \mathrm{t}=2.1653)$ and $\operatorname{TDS}(\mathrm{r}=0.8037, \mathrm{t}=$ 2.7013). A significant positive correlation was found between hardness with $\mathrm{pH}(\mathrm{r}=0.7379$, $\mathrm{t}=2.1866)$. While hardness showed negative correlation with TSS $(\mathrm{r}=0.9878, \mathrm{t}=12.6862)$. Negative correlation was found of $\mathrm{SO}_{4}^{2-}$ with TSS $(\mathrm{r}=0.8991, \mathrm{t}=4.1078) . \mathrm{SO}_{4}^{2-}$ showed significant positive correlation with $\mathrm{pH}(\mathrm{r}=0.7537, \mathrm{t}=2.2936), \mathrm{HRD}(\mathrm{r}=0.9392, \mathrm{t}=5.4704)$, turbidity $(\mathrm{r}=0.8543, \mathrm{t}=3.2871)$ and $\mathrm{EC}(\mathrm{r}=0.8061, \mathrm{t}=2.7263)$.

Turbidity showed significant positive correlation with HRD $(r=0.91, t=4.3896)$ EC $(\mathrm{r}=0.7465, \mathrm{t}=2.2438), \mathrm{Cl}^{-}(\mathrm{r}=0.7405, \mathrm{t}=2.203)$ and negative correlation with TSS $(\mathrm{r}$ $=-0.8816, \mathrm{t}=3.7356)$ and $\operatorname{TDS}(\mathrm{r}=-08703, \mathrm{t}=3.5340)$. BOD showed significant positive correlation with $\mathrm{Cl}^{-}(\mathrm{r}=0.9027, \mathrm{t}=4.125)$, $\mathrm{EC}(\mathrm{r}=0.743, \mathrm{t}=2.606)$, HRD $(\mathrm{r}=0.9640, \mathrm{t}=2.479), \mathrm{Mg}(\mathrm{r}=0.885, \mathrm{t}=3.8039)$ and turbidity $(\mathrm{r}=0.883, \mathrm{t}=3.770)$.

\section{Conclusion}

All the physico-chemical variables of Kosi river water at Kosi are within the highest desirable limit or maximum permissible limit set by WHO except turbidity and BOD which recorded high values. Kosi water recorded higher values of $\mathrm{Mg}$ than $\mathrm{Ca}$. Soil erosion and mining of dolomite in the region can be attributed to high values of magnesium than the calcium in the river water. A large number of factors and geological conditions influence the correlations between different pairs directly or indirectly. An appreciable significant positive correlation have been recorded for chloride with $\mathrm{pH}, \mathrm{Mg}, \mathrm{Na}$, hardness and TSS and sodium with hardness, EC and $\mathrm{SO}_{4}{ }^{2-}$. A significant negative correlation was found between potassium with turbidity, $\mathrm{Cl}^{-}, \mathrm{EC}$ and hardness. 


\section{References}

1. Mayur C Shah, Prateek Shilpkar and Sangita Sharma, Asian J Chem. 2007, 19(5), 3449-3454.

2. Garg D K, Goyal R N and Agrawal V P, Ind. J. Envir. Prot. 1990, 10(5), 355-359.

3. Mitali Sarkar, Abarna Banerjee, Partha Pratim Parameters and Sumit Chakraborty, J. Indian Chem. Soc., 2006, 83, 1023-1027.

4. Vogel A.I, A text book of Quantitative Inorganic Analysis Including Elementary Instrumental Analysis $4^{\text {th }}$ Ed. The English Language Book Society and Langman. Co (a) 1978. P 837 (b) P 328-32 (c) 504-506 (d) 499-500 (e) 830-831.

5. Standard Methods for the Examination of Water and Waste Water, $20^{\text {th }}$ Ed., APHA, AWWA, WEF. Washington DC, 1998.

6. Goon A M, Gupta M K and Dasgupta B, Fundmental of Statistics, The World Press Pvt. Ltd. Calcutta, Vol I, 1986.

7. World Health Organization, Guidelines for drinking water quality-I, Recommendations, $2^{\text {nd }}$ Ed. Geneva WHO, 1993.

8. Trivedy R K and Goel P K, Chemical and Biological Methods for Water Pollution Studies, Environmental Publication, India, 1986.

9. Rao S.M and Mamatha P, Curr. Sci. 2004, 87, 942.

10. Bhandari N S and Pande R K, Solute Dynamics of River Sarju in the Central Himalayas, India, In Ecology of the Mountain Waters, Bhatt S.D. and Pande R.K. Ashish Pub. New Delhi, 1991, 104-124.

11. Bhoi D K, Raj D S, Metha Y M, Chauhan M B and Machhar M T, Asian J. Chem, 2005, 17404. 


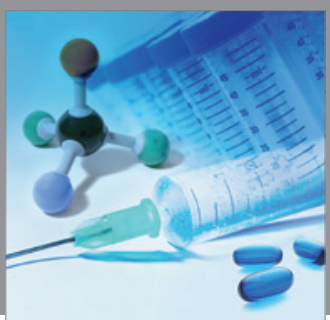

International Journal of

Medicinal Chemistry

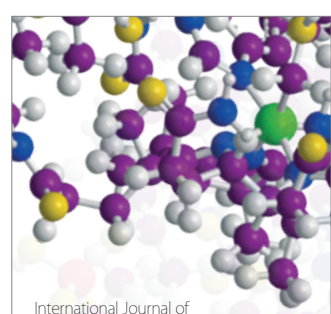

Carbohydrate Chemistry

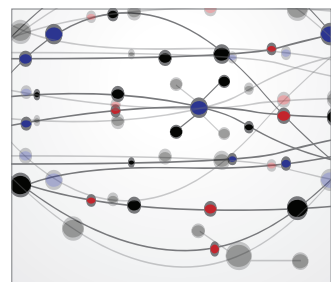

The Scientific World Journal
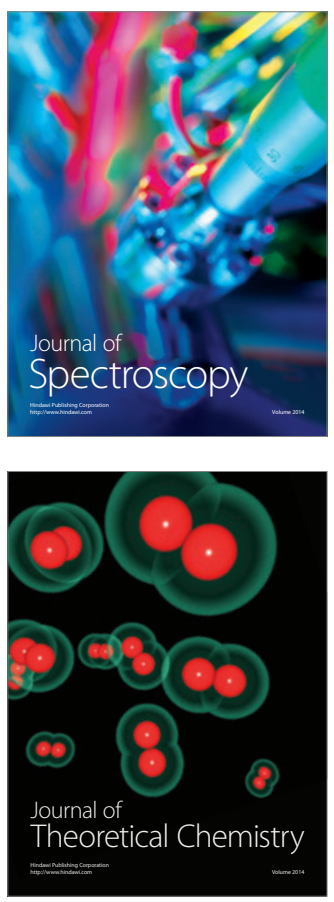
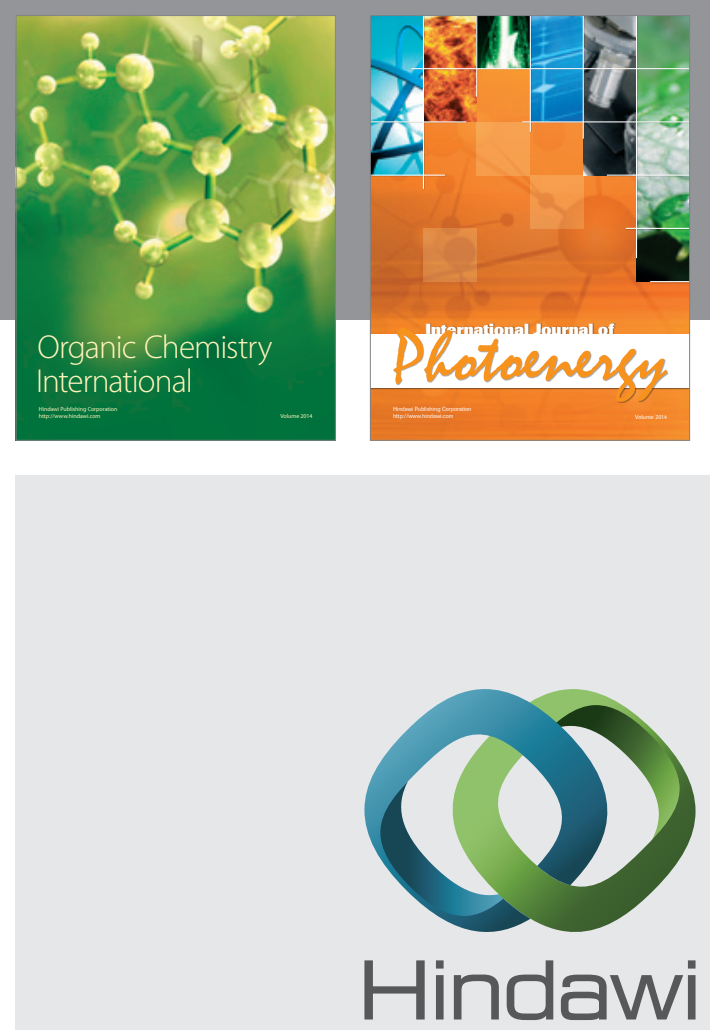

Submit your manuscripts at

http://www.hindawi.com
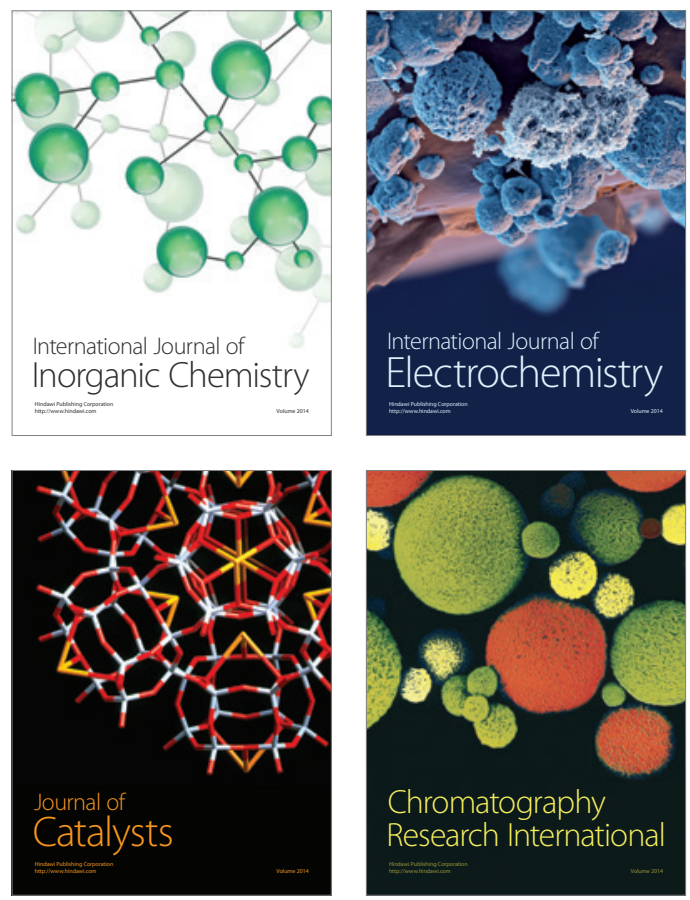
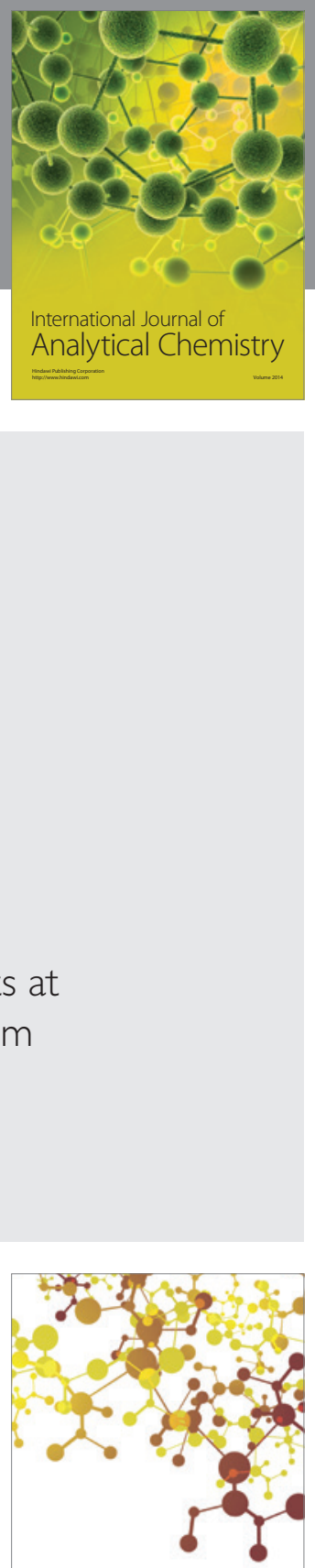

Journal of

Applied Chemistry
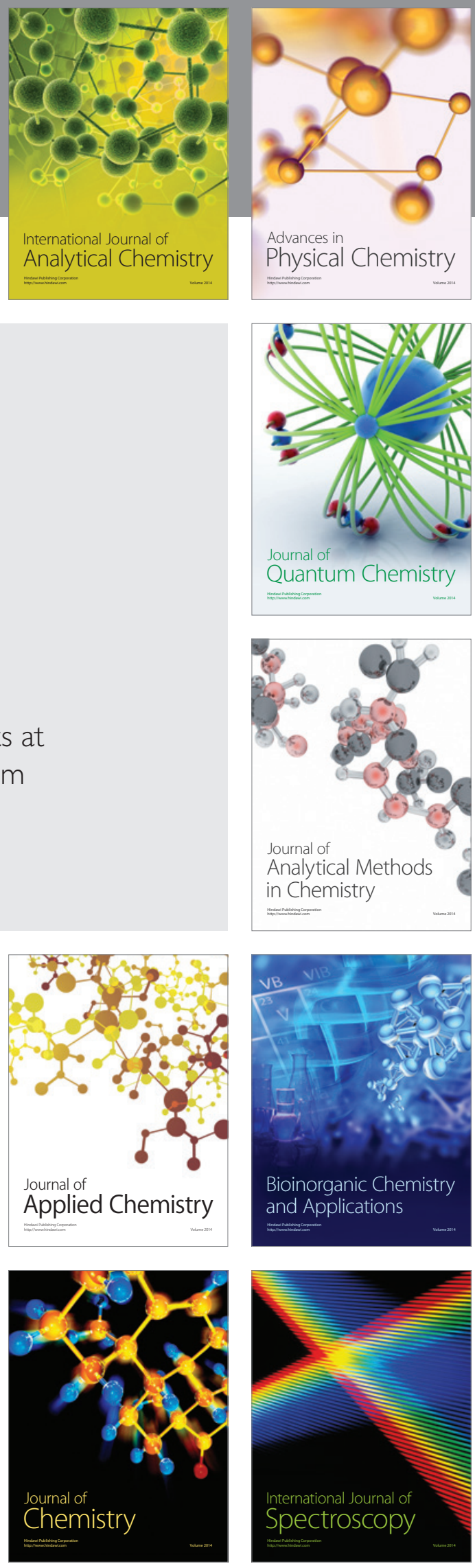